\title{
A NEW SPECIES OF AMPHIDROMUS ALBERS, 1850 (GASTROPODA: STYLOMMATOPHORA: CAMAENIDAE) FROM CHINA, WITH NOTES ON AMPHIDROMUS SPECIES
}

\author{
YUNG-CHING WANG ${ }^{1 *}$, ZHE-YU CHEN ${ }^{2}$ \\ 1Shenyang, Liaoning Province, China (e-mail: melanostictus@foxmail.com); \\ (1) https://orcid.org/0000-0003-4937-6116 \\ ${ }^{2}$ School of Life Sciences, Nanjing University, China (e-mail: chenzheyu1998@163.com); \\ (1) https://orcid.org/0000-0002-4150-8906 \\ *corresponding author
}

ABSTRACT: Amphidromus zelosus n. sp. from Guangxi Zhuang Autonomous Region, China, is described and illustrated. A. wani He et Zhou, 2017 is synonymised with A. qiongensis He et Zhou, 2017. Additional data on A. sinensis sinensis (Benson, 1851) are given.

KEY WORDS: taxonomy; systematics; new species; tree snails

\section{INTRODUCTION}

Amphidromus Albers, 1850 is a speciose genus of tropical arboreal camaenids that is widely distributed from South and Southeast Asia to northern Oceania (WANG 2021). The first report of this genus from China was $A$. sinensis by BENSON (1851); 130 years later, CHEN \& GAO (1984a) reported another species from Hainan Island as $A$. rhodostylus Moellendorff, 1901. This identification was adopted by manifold subsequent studies (CHEN \& GAO 1984b, 1987, QI et al. 1985, Du et. al. 2013). Nonetheless, in HE \& ZHOU (2017), this species was recognised as two species new to science, namely $A$. wani and $A$. qiongensis; additionally, HE \& ZHOU (2017) described from Yunnan Province a new subspecies, A. sinensis

\section{MATERIAL AND METHODS}

Specimens studied in this work were deposited in the Mollusc collection of the Museum of Hebei University (HBUMM, Baoding, Hebei Province, China) or Yung-Ching Wang's private collection (WYCC, Shenyang, Liaoning Province, China). Images of specimens in public repositories were also examined. Shells were measured with a mechanical vernier calli- qimingi He et Zhou, 2017, and recorded A. dautzenbergi Fulton, 1899 (disproven senior synonym of $A$. pervariabilis Bavay et Dautzenberg, 1909 (WANG 2019)) from Guangxi Zhuang Autonomous Region simultaneously. Furthermore, SUTCHARIT \& PANHA (2011) reported one specimen of $A$. mundus (Pfeiffer, 1853) labelled as "Borneo? China?". In the present study, A. zelosus n. sp., is described from Guangxi Zhuang Autonomous Region, and a rebuttal to the notion that the $A$. aff. rhodostylus population in Hainan Island comprises two species is proposed. Information concerning the type specimen and type locality of $A$. sinensis sinensis, which is practically known solely from its original description, is also presented. per by the first author to the nearest $0.05 \mathrm{~mm}$. Photos were downloaded from the Internet or taken using a Canon ${ }^{\circledR}$ 5D Mark IV camera attached with Canon ${ }^{\circledR}$ $100 \mathrm{~mm}$ Macro lens, stacked with Zerene Stacker ${ }^{\circledR}$ 1.04. and modified in Adobe Photoshop ${ }^{\circledR}$ CS6. The terminology formulated by INKHAVILAY et. al. (2017) to describe shell colouration of Amphidromus was used. 


\section{SYSTEMATIC PART}

\section{Family Camaenidae Pilsbry, 1895}

Genus Amphidromus Albers, 1850

Type species: Helix perversus L., 1758, subsequently designated by Martens in ALBERS (1860: 184)

Amphidromus zelosus n. sp.

Fig. 1

Amphidromus sp. HE \& ZHOU 2017: 7, fig. 11.

Type material. Holotype, HBUMM 10049 (dry shell, shell height $30.25 \mathrm{~mm}$, shell width $21.20 \mathrm{~mm}$ ), Baise City (百色市), Guangxi Zhuang Autonomous Region (广西壮族自治区), China. Paratype: HBUMM 10050 (one dry shell, shell height $29.90 \mathrm{~mm}$, shell width $21.30 \mathrm{~mm}$ ), same data as the holotype.

Description. Shell conical, dextral, solid, consisting of approximately 6 moderately inflated whorls, exterior smooth, sutures slightly impressed, base angular. Umbilicus reduced to a slit. Aperture auriform. Peristome somewhat expanded but not bent or thickened. Colouration basically in white and includes two intersecting, brown bands: band 2 axial stripes, while band 3 a spiral stria located on shell's periphery. Both bands first appear around the 2.5 whorls and terminate before the last half whorl.

Etymology. The name of this new species is derived from the Latin word zèlosus, meaning zealous, which embodies the first author's enthusiasm in malacology.

Remarks. Live samples of $A$. zelosus n. sp. were unavailable to the present study, but one specimen photographed by HE \& ZHOU (2017) alive, which is a conchological sub-adult with thin peristome, is likely this species. Its head, tentacles, and foot are greyish brown, and its mantle has a green hue.

Owing to their similar size and colouration, some individuals of $A$. pervariabilis (especially of varieties A. p. minor and A. p. goniostoma) and A. tanyai Panha, 1996 may look akin to A. zelosus n. sp. Contrastingly, A. zelosus n. sp. exhibits dark axial streaks on the shell. Some juveniles of larger Amphidromus s. s., e.g. A. atricallosus (Gould, 1843), resemble A. zelosus n. sp.; nevertheless, they are easily separable in that juvenile Amphidromus do not possess an expanded peristome.

Distribution. Based on current information, this new species is confined to the type locality.

\section{Amphidromus qiongensis He et Zhou, 2017}

Figs 2-3

Amphidromus rhodostylus CHEN \& GAO 1984a: 130, fig. 143; CHEN \& GAO 1984b: 11, pl. 3, fig. 11; QI et al. 1985: 81, text figure; CHEN \& GAO 1987: 112, fig. 144; DU et. al. 2013: 43, figs 1-3 (misidentification)

Amphidromus qiongensis HE \& ZHOU 2017: 4-5, figs 6-7.

Amphidromus wani HE \& ZHOU 2017: 3-4, figs 1-5; THACH 2020: 81, fig. 853 (new synonym)

Type locality. "Dongfang County, Hainan Province, China"

Material examined. WYCC/1, Jiangfengling, Ledong Li Autonomous County, Hainan Province, China; WYCC/2, Dongfang City, Hianan Province, China.

Remarks. In the population of this species, substantive transition in shell colour, the prime diagnostic trait indicated by HE \& ZHOU (2017), has been observed (SHENG-ZHUO HUANG, pers. comm.); it could, as a result, be suspected that differences in shell colour and texture, in the present case, reflect differences in individual growth stages or the collecting season, rather than in the genetics. A molecular phylogenetic analysis shows that Amphidromus samples morphologically identified as both species are monophyletic in comparison to other Amphidromus species (CHITSE LEE, pers. comm.), which substantiates our allogeneic treatment. The first revisor's power is herein exercised to confer nomenclatural priority upon A. qiongensis He et Zhou, 2017.

HE \& ZHOU (2017) expounded that the type morph of A. rhodostylus (A. r. rhodostylus) is different from $A$. qiongensis, which, judging from coloured photographs of the lectotype of $A$. $r$. rhodostylus, is correct. Though HE \& ZHOU (2017) did not investigate the rest of the taxa assigned to $A$. rhodostylus, and that $A$. qiongensis, A. r. nigrolineatus, and A. r. rhabdotus sometimes appear alike, $A$. qiongensis remains distinguishable from A. rhodostylus, since they show a markedly different range of variation in shell colouration.

\section{Amphidromus sinensis sinensis (Benson, 1851)}

Fig. 4

Bulimus sinensis BENSON 1851: 264; KÜSTER \& PFEIFFER 1845-1855: 67-68, pl. 20, figs 1-2.

Amphidromus sinensis: FULTON 1896: 80; PILSBRY 1900: 190-191, pl. 62, figs 64-65; GUDE 1914: 182-183; LAIDLAW \& SOLEM 1961: 660.

Remarks. In the original description of $A$. sinensis sinensis BENSON (1851) provided the measurements of only one shell and used the singular form of the noun "specimen", which signifies a holotype designated by monotypy. The specimen depicted in KÜSTER \& PFEIFFER (1845-1855), which is the "type shell" (in other words, the holotype) according to FULTON (1896), has a "lilac-coloured" peristome and one black streak immediately behind it, which 


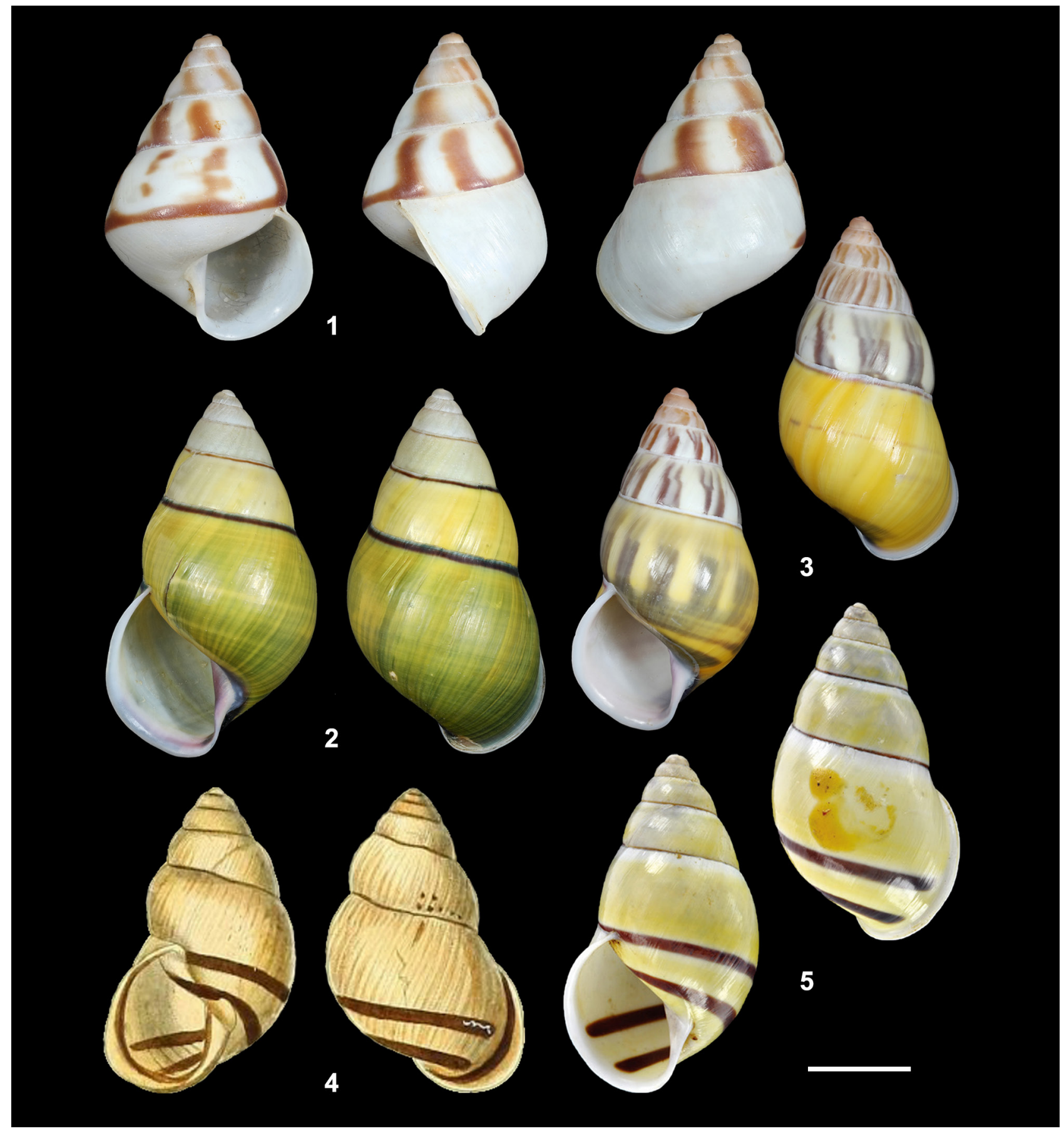

Figs 1-5. Shells of Amphidromus spp: 1 - A. zelosus n. sp. (holotype, HBUMM 10049); 2-3 - A. qiongensis (WYCC); 4 - A. sinensis sinensis (holotype, hand-drawn); $5-A$. s. vicarius (erroneously presumed syntype of $A$. s. sinensis, University Museum of Zoology Cambridge, Cambridge, UK). Scale bar $10 \mathrm{~mm}$

resembles that of $A$. koonpoi Thach et Huber, 2018 (a probable synonym of $A$. roseobiatus Fulton, 1896). These traits are highly unique; beside a "broader" shell, they are the chief characters that separate $A$. s. sinensis from $A$. s. vicarius Fulton, 1896 (FULTON 1896, Pilsbry 1900). A. s. vicarius (e.g. Mitra et al. 2005, NATURAL History MUSEUM (UK) 2014, NATURALIS BIODIVERSITY CENTER 2020) constitute the vast majority of $A$. sinensis collections, and except for the holotype of $A$. s. sinensis, the specimen reported by TRIPATHY et. al. (2018) is the only specimen on which we identified a "lilac-coloured" peristome and one black streak immediately behind it, although the streak is far from pronounced and is only visible between band 4 and band 5 from inside the aperture. The holotype of $A$. s. sinensis was surmised to be missing (PILSBRY 1900, LAIDLAW \& SOLEM 1961). It has not been located in the collections of the Oxford 
Museum of Natural History, the Museum of Zoology of University of Cambridge, or the Natural History Museum in London. SUTCHARIT et al. (2015) discovered three specimens in Benson's collection (Fig. 5), and assumed them to be possible syntypes of $A$. s. sinensis. Their supposition is incorrect because the type material of this subspecies is the holotype instead, as explained above; moreover, morphologically, those three specimens are A. s. vicarius Fulton, 1896 rather than A. s. sinensis. PILSBRY (1900) suspected that the holotype of A. s. sinensis may have been transferred to the collection of Dohrn, but no specimen claimed to be Benson's type material was found in Dohrn's surviving collection in Warsaw, Poland (TOM WHITE, pers. comm.).

BENSON (1851) only vaguely stated the type locality of $A$. sinensis sinensis as southern China, whereas LAIDLAW \& SOLEM (1961) cited the locality data documented in BENSON (1851) as Canton [Guangzhou,

\section{REFERENCES}

Albers J. C. 1850. Die Heliceen, nach natürlicher Verwandtschaft systematisch geordnet. T. C. F. Enslin, Berlin.

https://doi.org/10.5962/bhl.title.11507

Albers J. C. 1860. Die Heliceen nach natürlicher Verwandtschaft systematisch geordnet. Zweite Ausgabe, nach dem hinterlassenen Manuskript besorgt von Eduard von Martens. Leipzig, Saxony State, Germany. https://doi.org/10.5962/bhl.title.11218

BAVAY A., DAUTZENBERG P. 1909. Molluscorum terrestrium tonkinorum diagnoses. Journal de Conchyliologie 56: 229-251 (1908).

BENSON W. H. 1851. Description of new landshells from St. Helens, Ceylon, and China. The Annals and Magazine of Natural History, Second Series 7: 262-265.

CHEN D.-N., GAO J.-X. 1984a. Molluscs from agricultural regions of China. Agriculture Publishing House, Bejing, China. (in Chinese)

CHEN D.-N., GAO J.-X. 1984b. Preliminary report on terrestrial mollusc in Guangdong (Hainan Island) with new domestic records. Sichuan Journal of Zoology 03: 10-17.

CHEN D.-N., GAO J.-X. 1987. Economic fauna of China. Terrestrial molluscs. Science Press, Beijing, China.

DU L., XU Q., WU M. 2013. The monsoon forest refuge of the only Chinese Amphidromus. Tentacle 21: 43-44.

FUlTON H. C. 1896. A list of the species of Amphidromus, Albers, with critical notes and descriptions of some hitherto undescribed species and varieties. The Annals and Magazine of Natural History, Sixth Series 17: 66-94. https://doi.org/10.1080/00222939608680326

FULTON H. 1899. Descriptions of supposed new species of Streptaxis and Amphidromus. Proceedings of the Malacological Society of London 3: 302-303.
Guangdong Province], South China, which we believe was a misreading of the name of Dr. Cantor, who was mentioned in the text of BENSON (1851) almost immediately after the locality data for $A$. sinensis. Unaware of LAIDLAW \& SOLEM's (1961) error, HE \& ZHOU (2017) reproduced it. Actually, however, the precise origin of $A$. s. sinensis is still in suspense.

\section{ACKNOWLEDGEMENTS}

We are much indebted to Dr ChITSE LeE, Dr TOM WHITE, and Dr SHENG-ZHUO HUANG, who furnished us with private data. Two anonymous referees' helpful comments on the manuscript are acknowledged with gratitude. In addition, the first author thanks his parents for their encouragement which facilitated his work.

Gould A. A. 1843. Shells not long since announced as having been received from the Rev. Francis Mason, missionary at Tavoy, in British Burmah. Proceedings of the Boston Society of Natural History 1: 139-141, 144.

GUDE G. K. 1914. The fauna of British India, including Ceylon and Burma. Taylor and Francis, London, UK.

HE J., ZHOU Q. 2017. Records of Amphidromus from south China. Shell Discoveries 2: 3-7.

INKHAVILAY K., SUTCHARIT C., BANTAOWONG U., ChANABUn R., SiriWut W., SRISONCHAI R., PHOLYOTHA A., JIRAPATRASILP P., PANHA S. 2019. Annotated checklist of the terrestrial molluscs from Laos (Mollusca, Gastropoda). ZooKeys 834: 1-166. https://doi.org/10.3897/zookeys.834.28800

KÜster H. C., PfeIfFer L. 1845-1855. Die Gattungen Bulimus, Partula, Achatinella, Achatina und Azeca. In: Abbildungen nach der Natur mit Beschreibungen. Systematisches Conchylien-Cabinet von Martini und Chemnitz 1 (13) [(1)]: iii-xix, 1-395, pls 1-70. [p. 49-96, pls 19-24 [1853]; p. 97-232, pls 30-52 [1854]].

LAIDLAW F. F., SOlEM A. 1961. The land snail genus Amphidromus. A synoptic Catalogue. Fieldiana: Zoology 41: 503-677.

LINNAEUS C. 1758. Systema Naturae per regna tria naturae, secundum classes, ordines, genera, species, cum characteribus, differentiis, synonymis, locis. Tomus I. Editio decima, reformata. Laurentius Salvius: Holmiae. https://doi.org/10.5962/bhl.title.542

Mitra S. C., DeY A., RAMAKRISHNA 2004. Pictorial handbook-Indian land snails (Selected species). Zoological Survey of India, Kolkata, West Bengal State, India.

MÖLLENDORFF O. F. VON 1901. Zur BinnenmolluskenFauna von Annam, IV. Nachrichtsblatt der Deutschen Malakozoologischen Gesellschaft 33: 45-50. 
NATURAL History MUSEUM (UK) 2014. Dataset: Collection specimens. Resource: Specimens. Natural History Museum Data Portal. https://doi.org/10.5519/0002965

NATURAlis BIODIVERSiTy CENTER 2020. Amphidromus sinensis (Benson, 1851). Available online at https:// commons.wikimedia.org/wiki/File:Naturalis Biodiversity_Center_-_RMNH.MOL.288416_Amphidromus_sinensis_(Benson,_1851) -Camaenidae - Mollusc shell.jpeg (accessed $2 \overline{1}$ December 2020).

PANHA S. 1996. A new species of Amphidromus from Thailand (Stylommatophora: Camaenidae) Malacological Review 29: 131-132.

PilsBRY H. A. 1893-1895. Manual of conchology, structural and systematic, with illustrations of the species. Second series: Pulmonata. Vol. VIII, Helicidae, Vol. 6. Conchological Section, Academy of Natural Sciences, Philadelphia.

PILSBRY H. A. 1900. Manual of conchology, structural and systematic: with illustrations of the species, Vol. XIII. Australasian Bulimulidae: Bothriembryon, Placostylus. Helicidae: Amphidromus. Conchological Section, Academy of Natural Sciences of Philadelphia, Philadelphia, Pennsylvania State, USA.

QI Z.-Y., MA X.-T., LIU Y.-Y., CHEN D.-N., WANG Y.-X., ZHANG W.-Z., GAO J.-X. 1985. Atlas of animals of China. Vol. 4. Mollusca. Science Press, Bejing, China. (in Chinese)

SutCharit C., ABlett J., TONGKERD P., NAGgs F., PANHA S. 2015. Illustrated type catalogue of Amphidromus Albers,
1850 in the Natural History Museum, London, and descriptions of two new species. ZooKeys 492: 49-105.

SUTCHARIT C., PANHA S. 2011. Neotype designation and re-description of the vanishing tree snail, Amphidromus (Amphidromus) mundus (Pfeiffer, 1853) (Pulmonata: Camaenidae). The Raffles Bulletin of Zoology 59: 139-143. https://doi.org/10.3897/zookeys.492.8641

THACH N. N. 2020. New shells of South Asia. Volume 2. Seashells*Freshwater*Land Snails. With One New Genus and 140 New Species \& Subspecies, Reply to Comments Made in Error. 48HrBooks Company, Akron, Ohio State, USA.

Tripathy B., Sajan S., Sethy P. G. S., Chatterjee P., CHANDRA K. 2018. A new record expanding the range of Amphidromus sinensis (Benson, 1851) (Gastropoda: Camaenidae). Folia Malacologia 26: 263-266. https://doi.org/10.12657/folmal.026.022

WANG Y. C. 2019. Review on the synonymy concerning genus Amphidromus Albers, 1850 (Gastropoda: Camaenidae), with descriptions of new species. The Festivus 51: 297-305.

WANG Y. C. 2021. One new species and one new subspecies of Amphidromus Albers, 1850 (Gastropoda, Pulmonata, Camaenidae) from Southeast Asia. Xenophora Taxonomy 31: 47-50.

Received: December 31st, 2020

Revised: February 25th, 2021

Accepted: March 9th, 2021

Published on-line: March 19th, 2021 